УДК 544.541

\title{
СРАВНЕНИЕ РАДИАЦИОННОЙ СТАБИЛЬНОСТИ ХЛОРОФИЛЛОВЫХ ФРАКЦИЙ В СПИРТОВЫХ И АЦЕТОНОВЫХ ЭКСТРАКТАХ ВОДОРОСЛЕЙ LAMINARIA JAPONICA (МЬЯНМЫ)
}

\author{
(C) Тхан Тайк", А.А. Ревина, С.С. Лозинина, Э.П. Магомедбеков \\ Российский химико-технологический университет им. Д.И. Менделеева, \\ ул. Героев Панфиловцев, 20/1, Москва, 125480 (Россия), \\ e-mail: thanhtaik.iron@gmail.com
}

В работе выделены этанольные и ацетоновые экстракты из бурых водорослей Laminaria Japonica Jemo (D) и Jenit (M). Методом UV-VIS спектрофотометрии зарегистрированы спектры оптического поглощения исходных экстрактов и их изменения при различном разбавлении растворителями. Показано, что природа водорослей, способ их культивирования, природа растворителей влияют на эффективность экстракции ценных биологически активных соединений (БАС), включая наиболее важные из них - каротиноиды и хлорофиллы. Особое внимание в этой работе было уделено изучению радиационно-химических превращений спиртовых (этанол), ацетоновых, водно-этанольных (50\%) и водно-ацетоновых (50\%) растворов экстрактов водорослей при различных условиях моделирования окислительновосстановительных реакций за счет насыщения облучаемых растворов разными газами: кислородом воздуха, аргоном или закисью азота. Определена радиационно-химическая стабильность хлорофилловых фракций в разных видах водорослей в зависимости от условий радиолиза. Известно, что хлорофиллы часто используются в фармакологии, в качестве пищевого красителя, а в настоящее время в качестве компонентов светочувствительных слоев в нанофотонике. Данные по радиационной чувствительности биологических соединений из морских водорослей можно использовать для оценки их стабильности при радиационной стерилизации сырья и медицинских препаратов.

Ключевые слова: морские водоросли, экстракты, хлорофилл, спектрофотометрия, ионизирующее излучение, $\gamma$-лучи, ускоренные электроны, радиационная стабильность, радиационная чувствительность.

\section{Введение}

Бурые водоросли являются перспективным источником биологически активных веществ, таких как полиненасыщенные жирные кислоты, полисахариды, витамины, каротиноиды и др. [1]. Многие продукты метаболизма водорослей широко применяются в медицине [2, 3]. Из всех метаболитов особое внимание было уделено каротиноидам, поскольку экспериментально доказано, что каротиноиды в организме человека способны повышать иммунитет, снижать последствия стресса и воздействия ионизирующего излучения $[4,5]$. В последнее время в лучевой терапии активно применяют экстракты из бурых водорослей в виде «чая» с высоким содержанием каротиноидных фракций, в частности фукоксантина, в результате чего биологически активные соединения внутри живых организмов также подвергаются действию ионизирующего излучения. В работе [5] получены экспериментальные данные о радиационной стабильности фукоксантина и о частичной регенерации этого пигмента в пострадиационный период в присутствии молекулярного кислорода. Однако в отечественной и зарубежной литературе недостаточно сведений о радиационной ста-

Тхан Тайк- аспирант, e-mail: thanhtaik.iron@gmail.com Ревина Александра Анатольевна - доктор химических наук, профессор, ведущий научный сотрудник, e-mail: alex_revina@mail.ru

Лозинина Светлана Сергеевна - студентка, e-mail: lozinina-svetlanka@yandex.ru

Магомедбеков Эльдар Парпачевич - кандидат химических наук, доцент, заведующий кафедрой химии высоких энергий и радиоэкологии, e-mail: eldar@rctu.ru бильности других биологически активных соединений из бурых водорослей, включая хлорофилл, и данных по их деструкции при радиационной стерилизации. Отсутствуют данные по оптическим свойствам и радиационной стабильности экстрактов из культивируемых водорослей Laminaria Japonica (Республика Мьянма).

\footnotetext{
* Автор, с которым следует вести переписку.
} 
В настоящей работе методом UV-VIS спектрофотометрии проведено исследование радиационнохимических превращений хлорофилловых фракций этанольных и ацетоновых экстрактов из водорослей Laminaria Japonica Jemo (D) и Jenit $(M)$ в зависимости от дозы облучения ( $\gamma$-лучи ${ }^{60}$ Cо), сравнение стабильности экстрактов водорослей, выделенных из образцов сырья, облученных в сухом виде при дозах, используемых при стерилизации (ускоритель электронов, Е 8 Мэв, длительность импульса 10 мкс).

\section{Экспериментальная часть}

В работе использованы два вида высушенных образцов водорослей Laminaria Japonica (Республика Мьянма) - D (Jemo) и М (Jenit). Экстракты готовили добавлением 200 мл растворителя к навеске водорослей массой 10 г. В качестве растворителей были выбраны спирт (этанол), ацетон, водные растворы $50 \%$ этанола и 50\% ацетона. Растворы выдерживали в течение 10 дней при $\mathrm{T}_{\text {комн. }} \sim 22-25^{\circ} \mathrm{C}$. Установлено, что этого времени достаточно для полного экстрагирования хлорофиллов. Для измерения спектров оптического поглощения растворов после фильтрации и после облучения использовали спектрофотометр (СФ-2000) или Spectrophotometer Hitachi 3310, кварцевые кюветы с длиной оптического пути l=1 см. Раствором сравнения был соответствующий растворитель, температура измерения $\mathrm{T}_{\text {комн. }} 22^{\circ} \mathrm{C}$. Для облучения растворов экстрактов водорослей использовали установку $\gamma-{ }^{60}$ Со (РХМ- $\gamma-$ Со-60, РХТУ), мощность дозы, определенная методом ферросульфатной дозиметрии [6], была равной 0,09-0,10 Гр/сек, доза облучения варьировалась от 0,2 до 1,3 кГр. Облучение образцов водорослей в сухом виде проводилось потоком ускоренных электронов при дозе 15-18 кГр (ускоритель УЭЛВ-10-10-С-70, ИФХЭ РАН).

\section{Обсуждение результатов}

Спектры оптического поглощения 100\% ацетоновых экстрактов (СФ-2000) (M-I Jenit и D-I Jemo), измеренные сразу после $\gamma$-облучения и через несколько часов (пострадиационный эффект, ПРЭ), представлены на рисунке 1. Спектральные характеристики (I-V) относятся к полосам поглощения отдельных компонентов экстрактов, включая каротиноидную фракцию полосы (I) в интервале длин волн $\lambda \sim 380-450$ нм и хлорофилловую (V) - $\lambda \sim 630-700$ нм. В этой серии экспериментов и облучение образцов, и измерение их спектров оптического поглощения проводилось в присутствии кислорода воздуха.
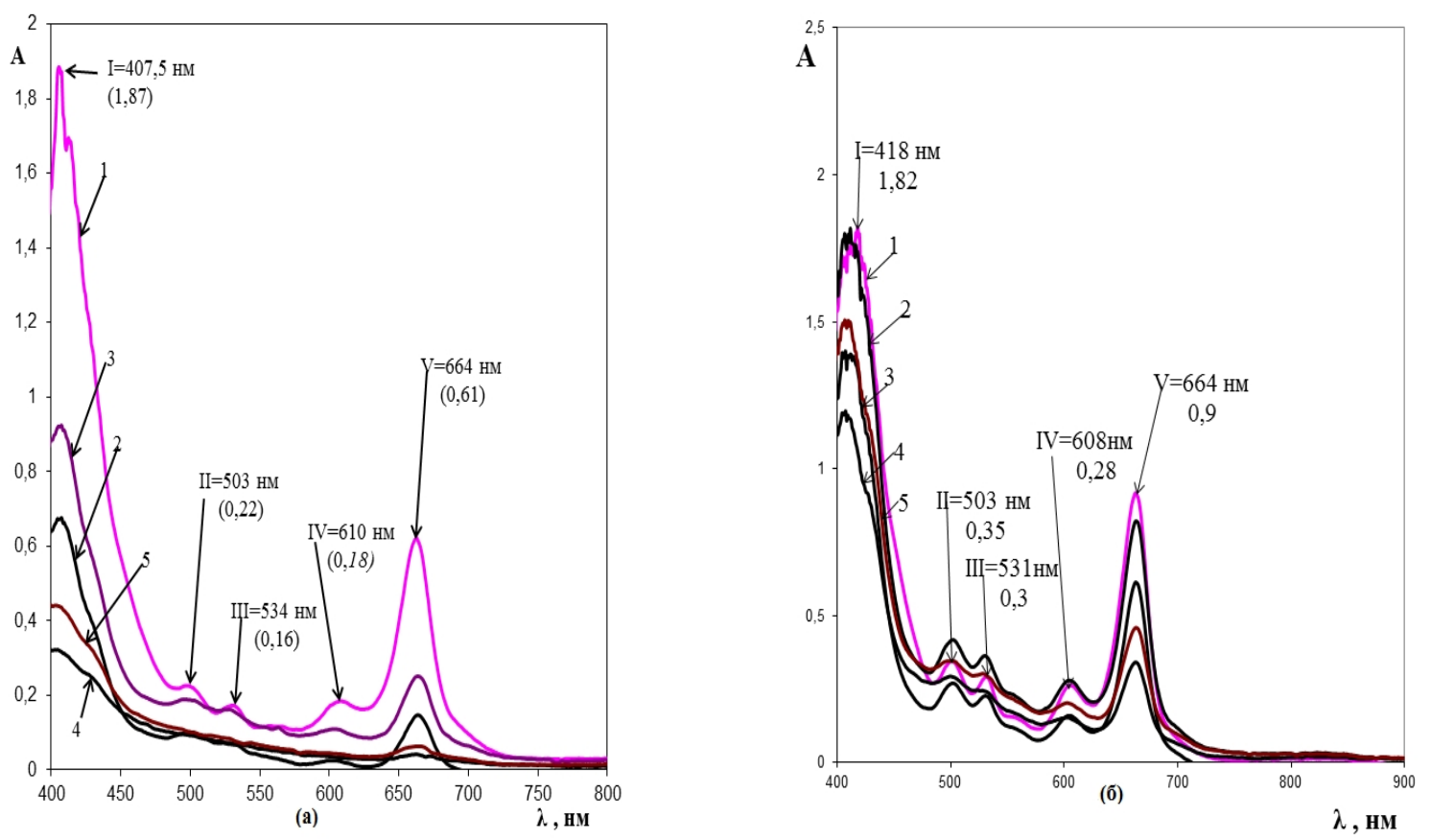

Рис. 1. Спектры оптического поглощения 100\% ацетоновых экстрактов M-I (Jenit) - a, D-I (Jemo) б: 1 - исходный образец, 2 - после облучения, D = 0,65 кГр, 3 - 2 ч (ПРЭ), 4 - после облучения, $\mathrm{D}=1,30$ кГр, $\mathbf{5}-4$ ч (ПРЭ) 
Сравнение оптических характеристик спектров M-I и D-I (рис. 1) после облучения при разных дозах позволяет сделать вывод о более высокой радиационной чувствительности биологических компонентов в экстрактах водорослей Jenit-M-I. Так, в образце Jenit-M-I поглощение, соответствующее хлорофиллам, уменьшается в 6 раз, при поглощенной дозе 0,65 кГр (с 0,6 до 0,1), в то время как в образце Jemo-D-I только на $\sim 30 \%$ (с 0,9 до 0,6 ).

Спектры оптического поглощения исходных 50\% водно-ацетоновых экстрактов (M-II Jenit и D-II Jemo) и их изменения после радиолиза представлены на рисунке 2.

Как можно видеть по изменению интенсивности характерных полос оптического поглощения, радиационно-химические превращения 50\% водно-ацетоновых экстрактов M-II (Jenit) и D-II (Jemo) различаются незначительно. При этом ранее было установлено, что в водно-этанольных экстрактах радиационная чувствительность БАС выше у М-II [7, 8].

На рисунке 3 представлены спектры оптического поглощения исходных 50\% водно-этанольных M-II (Jenit) и D-II (Jemo) растворов. Сравнение спектров показывает, что вклад хлорофилловой фракции в поглощении M-II намного выше, чем в D-II. B результате облучения этих растворов при дозе $=0,32$ кГр более сильно выражено изменение спектральных характеристик полос поглощения в спектре растворов М-II.

Данные по радиационной чувствительности экстрактов водорослей, полученные только на основании спектрофотометрических результатов изменения оптической плотности характерных полос поглощения в такой сложной по составу системе, позволяют сделать только оценку стабильности различных фракций при радиационной стерилизации фармпрепаратов из водорослей. Поэтому представляло интерес расширение возможностей радиационно-химических исследований тех же самых растворов экстрактов водорослей и сравнение их стабильности в разных условиях протекания окислительно-восстановительных реакций при насыщении растворов различными газами. В водно-этанольных растворах, насыщенных аргоном для удаления кислорода, при радиолизе воды образуются промежуточные короткоживущие частицы, такие как гидратированные электроны, е гедр, атомы водорода Н, обладающие высокими восстановительными потенциалами, и радикалы ОН, самые сильные окислительные реакционные центры. Однако в присутствии молекул этанола, активного акцептора радикалов $\mathrm{OH}$, образуются гидрокси-этильные радикалы, имеющие тоже высокие восстановительные свойства, поэтому в этих условиях протекают только восстановительные процессы с участием биологических молекул экстрактов.
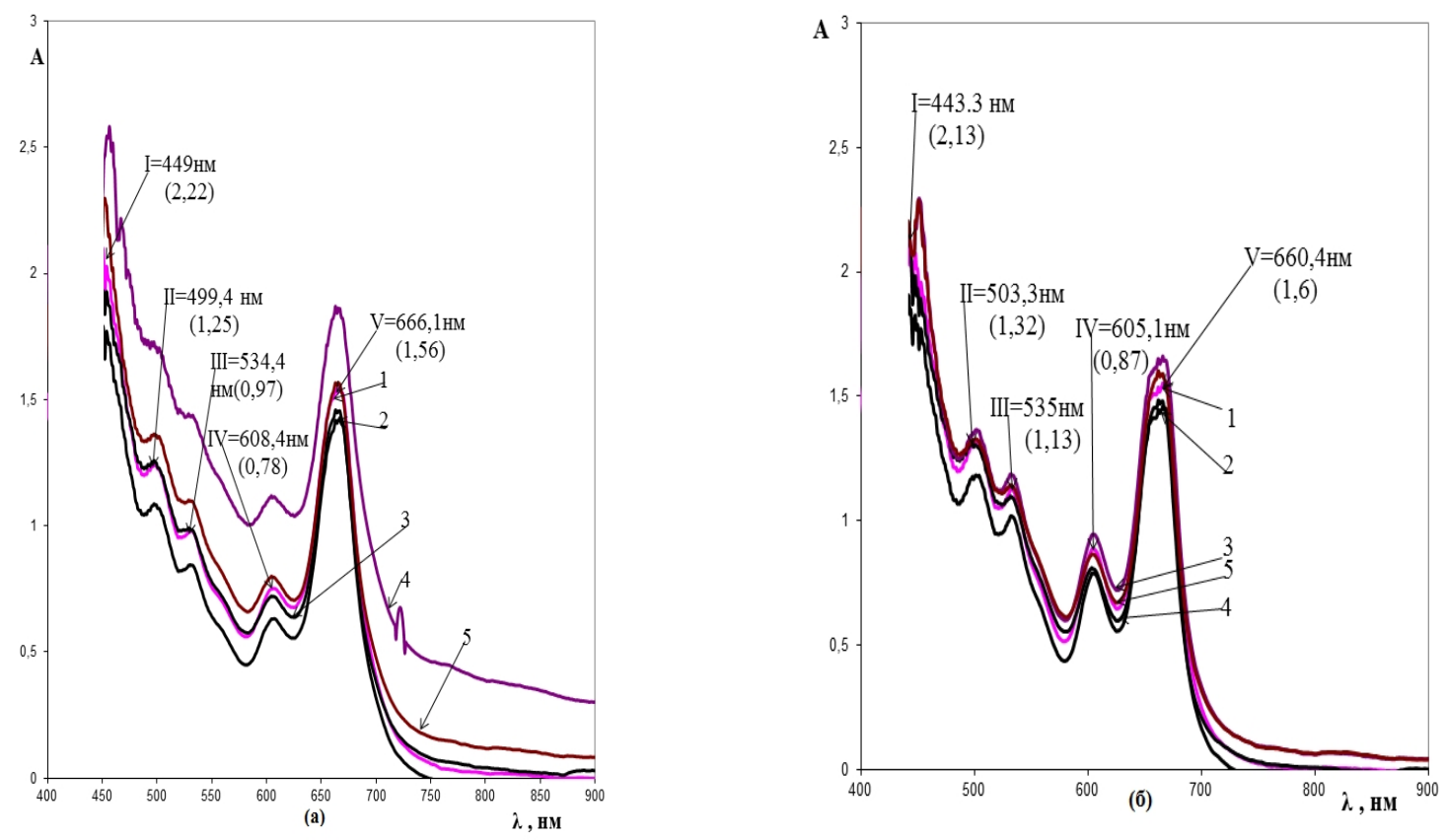

Рис. 2. Спектры оптического поглощения 50\% водно-ацетоновых экстрактов M-II (Jenit) - a D-II (Jemo), б: 1 - исходный образец, 2 - после облучения $\mathrm{D}=0,65 \kappa Г р, 3-$ ПРЭ 2 ч, 4 - после облучения $\mathrm{D}=1,30$ кГр, $5-\Pi Р Э 4$ ч 

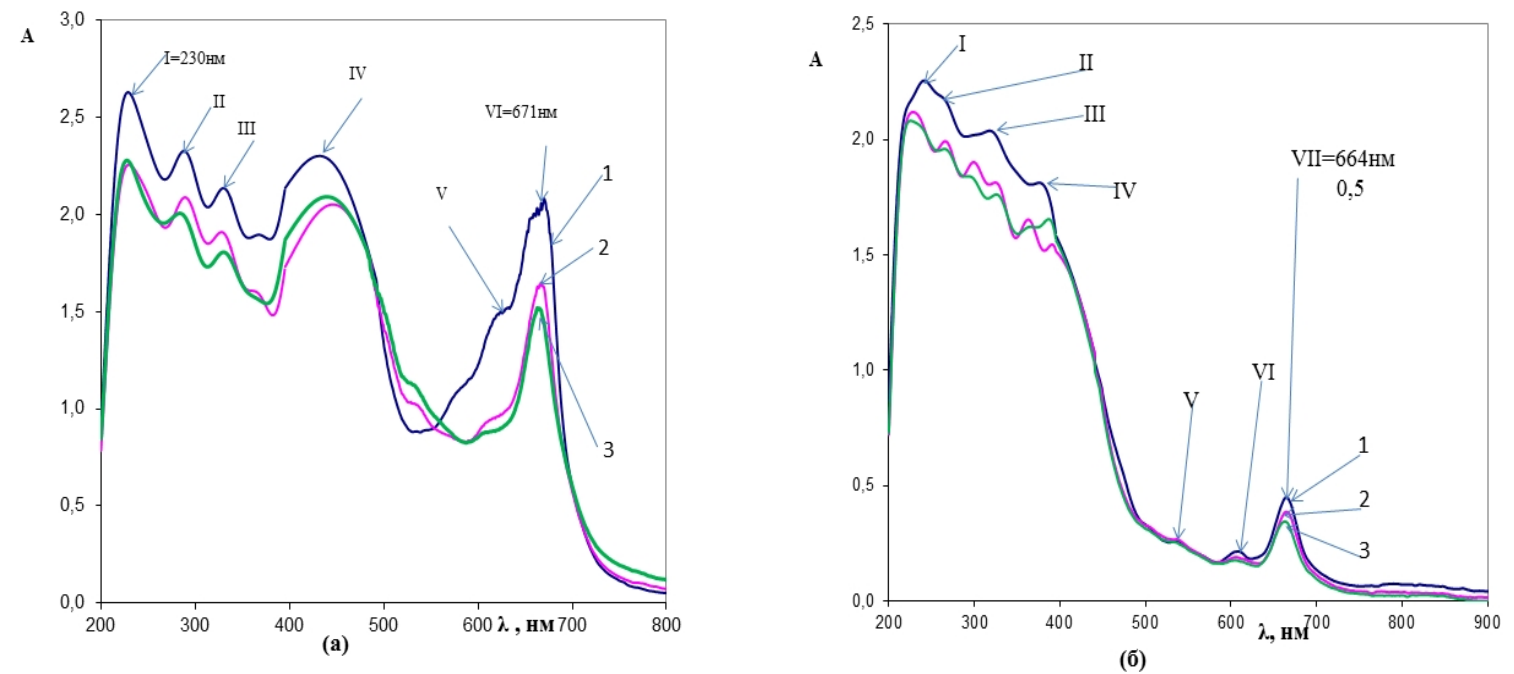

Рис. 3. Спектры оптического поглощения 50\% водно-этанольных экстрактов M -II (Jenit) - a D -II (Jemo) б: 1 - исходный образец, 2 - через 1 ч после $\gamma$-облучения ( $\mathrm{D}=0,32$ кГр), 3 - ПРЭ (1 месяц)

Продувка водно-этанольных растворов перед облучением закисью азота, $\mathrm{N}_{2} \mathrm{O}$ приводит к генерации дополнительного количества радикалов $\mathrm{OH}$, что увеличивает вклад реакций окисления и снижает стабильность биологических водорослей.

Спектры оптического поглощения исходных 50\% водно-этанольных экстрактов М-II (Jenit) и после облучения в присутствии кислорода воздуха (а), в анаэробных условиях после насыщения $\operatorname{Ar}($ б) и после насыщения $\mathrm{N}_{2} \mathrm{O}$ (в) представлены на рисунке 4. На вставках в увеличенном масштабе - полосы хлорофилла (V).

На рисунке 5 представлены спектры оптического поглощения исходных 50\% водно-этанольных экстрактов D-II (Jemo) и после облучения в присутствии кислорода воздуха (a), насыщенных $\mathrm{Ar}(\boldsymbol{\sigma})$ и $\mathrm{N}_{2} \mathrm{O}$ (в) в зависимости от дозы облучения.
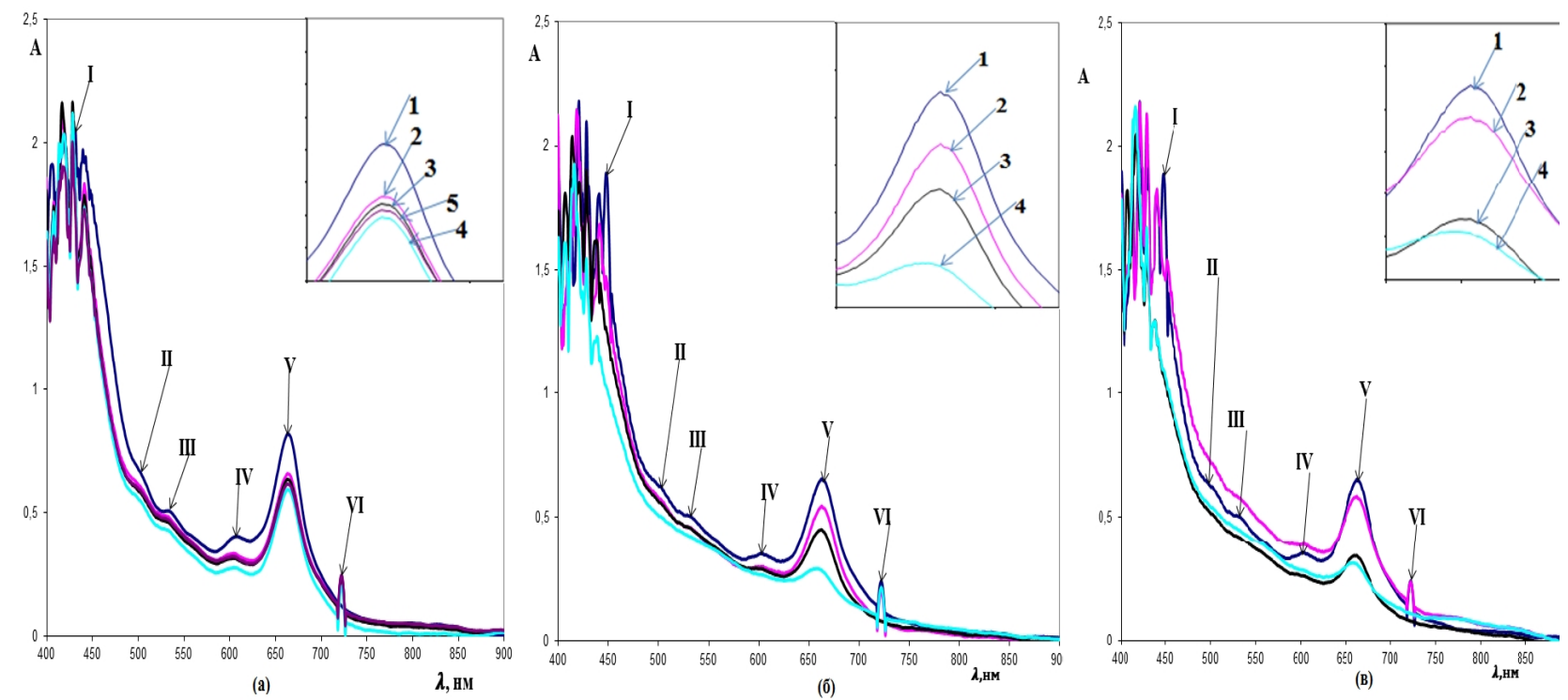

Рис. 4. Спектры оптического поглощения 50\% водно-этанольных экстрактов в присутствии кислорода M-II (Jenit) - а насыщенных $\mathrm{Ar}$ - б насыщенных $\mathrm{N}_{2} \mathrm{O}$ - в 1 - исходный образец, 2 - облучение, D=0,28 кГр, 3 - облучение, $\mathrm{D}=0,56$ кГр, 4 - облучение , $\mathrm{D}=1,1$ кГр 

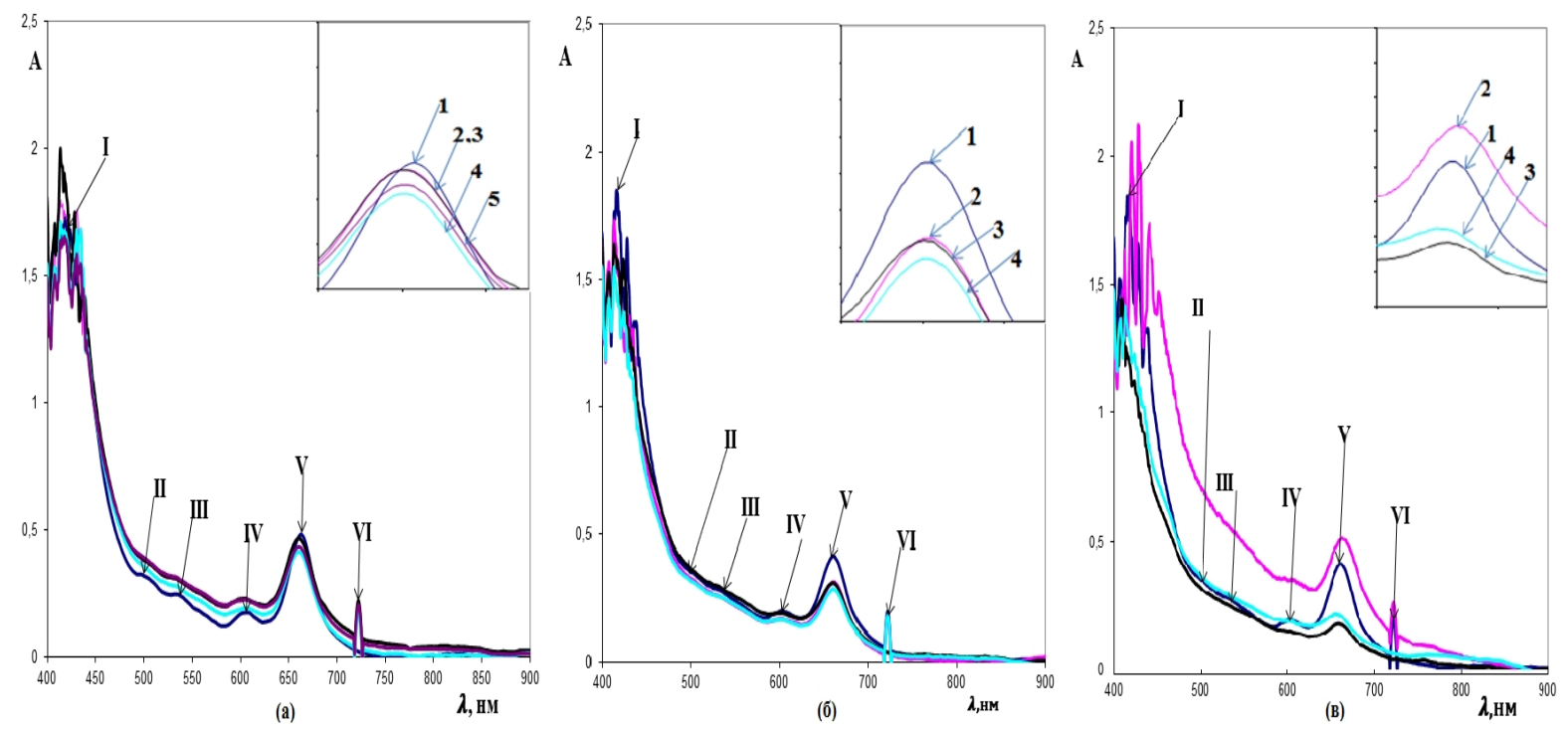

Рис. 5. Спектры оптического поглощения 50\% водно-этанольных экстрактов в присутствии кислорода D-II (Jето), - а насыщенных $\mathrm{Ar}-\boldsymbol{6}$ и насыщенных $\mathrm{N}_{2} \mathrm{O}$ - в. На ставках: полосы (V) хлорофилловой фракции: 1 - исходный образец, 2-4 - облученные образцы, соответственно дозы, D, кГр: 0,28 - 2, $0,56-3,1,1-4$

Особое внимание было уделено изучению эффективности экстракции биологически активных компонентов из макроводорослей Laminaria Japonica Jenit (M) и Jemo (D) (Республика Мьянма) и, для сравнения, микроводорослей Cylindrotheca closterium (ИнБЮМ, г. Севастополь), облученных в сухом виде ускоренными электрономи при дозе 15-18 кГр (ускоритель УЭЛВ-10-10-С-70, ИФХЭ РАН). Дополнительное отличие этих двух групп водорослей в том, что водоросли Laminaria Japonica Jenit (M) и Jemo (D) культивированы в пресной воде, а Cylindrotheca closterium - в морской воде. Результаты исследования оптических свойств и радиационно-химических превращений экстрактов водорослей Cylindrotheca closterium представлены ранее в работах $[9,10]$.

Для облучения были подготовлены по два образца трех видов водорослей (навески 2,5 г каждого образца), которые помещались в целлофановые пакеты. После облучения три образца разных водорослей помещались в колбы с этанолом (50 мл), а другие три образца тех же водорослей помещались в колбы с 50\% водно-этанольным раствором (50 мл). Для полной экстракции биологически активных веществ образцы растворов водорослей выдерживались при $\mathrm{T}_{\text {комн. }}$ в течение 10 суток.

Спектры оптического поглощения этанольных растворов водорослей Cylindrotheca closterium представлены на рисунке 6.

На рисунке 7 представлены спектры оптического поглощения этанольных М-I и водно-этанольных растворов М-II макроводорослей Jenit до и после импульсного облучения потоком ускоренных электронов при $\mathrm{D} \sim 18$ кГр.

Рис. 6. Спектры оптического поглощения этанольных растворов экстрактов из высушенной биомассы водорослей Cylindrotheca closterium - 1, этанольных растворов экстрактов из сухой биомассы водорослей, облученной при $\mathrm{D}=22$ кГр - 2. Спектрофотометр Hitachi 3310

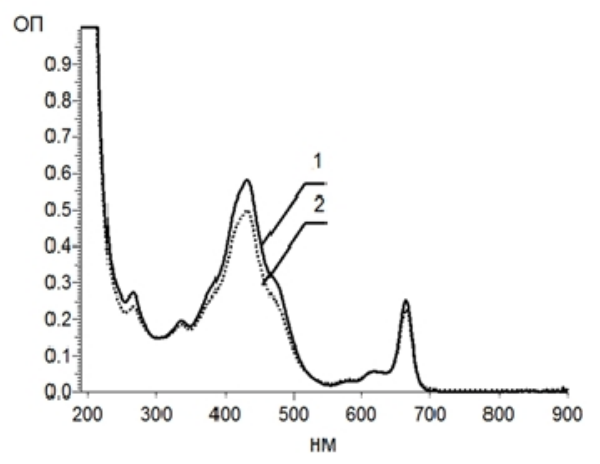



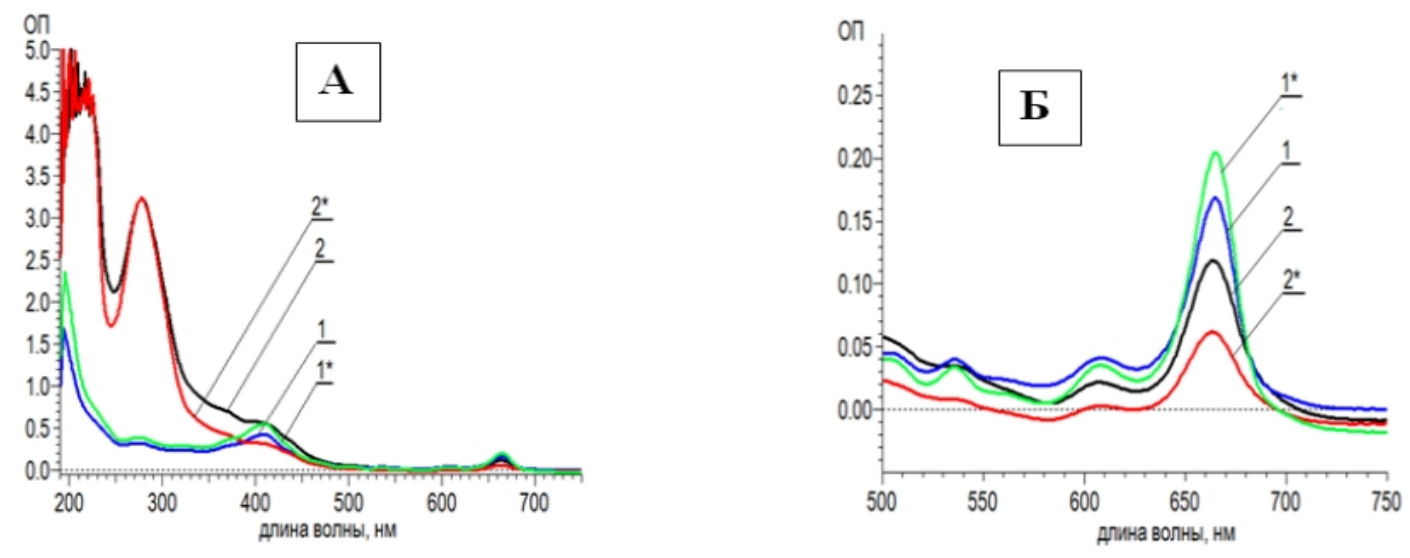

Рис. 7. А - спектры оптического поглощения исходных этанольных Jenit (M-I) - 1 и водно-этанольных экстарактов Jenit (M-II) - 2; этанольных экстрактов после облучения Jenit (M-I) - 1* и водно-этанольных экстрактов Jenit (M-II) - 2*; Б - спектры оптического поглощения в области длин волн (580-700 нм) хлорофилловых фракций исходных этанольных экстрактов Jenit (M-I) - 1 и водно-этанольных экстрактов Jenit (M-II) - 2 и соответственно после облучения - 1* и - 2*

Спектры оптического поглощения этанольных и водно-этанольных растворов водорослей Jemo ( D-I и D-II ) представлены на рисунке 8.

Среди полученных результатов по изучению эффективности экстракции биологически активных соединений (БАС) из различных видов макроводорослей (Jemo и Ienit) следует обратить внимание на более высокую избирательную способность экстракции этанольных растворов по отношению к хлорофилловой (580-700 нм) и каротиноидной (400-450 нм) фракциям (рис. 7 и 8). При анализе спектральных характеристик оптического поглощения необходимо учитывать, что спектр «каротиноидной» фракции представляет собой суперпозицию полос, включая наложение синих полос поглощения хлорофиллов $a$ и $b$ в этой же спектральной области - (430-450 нм). Высокий выход каротиноидов, и именно фукоксантина, определен методом тонкослойной хроматографии, ТСХ в этанольных экстрактах из микроводорослей Cylindrotheca closterium, культивирование которой проводят в морской воде [10]. В этой же работе приведены данные по экстракции каротиноидов из других водорослей. Показано, что каротиноиды методом ТСХ выделены из макроводорослей Jemo и Jenit, полосы оптического поглощения лежат в области 430-450 нм, но люминесцентные свойства отличны от свойств фукоксантина.
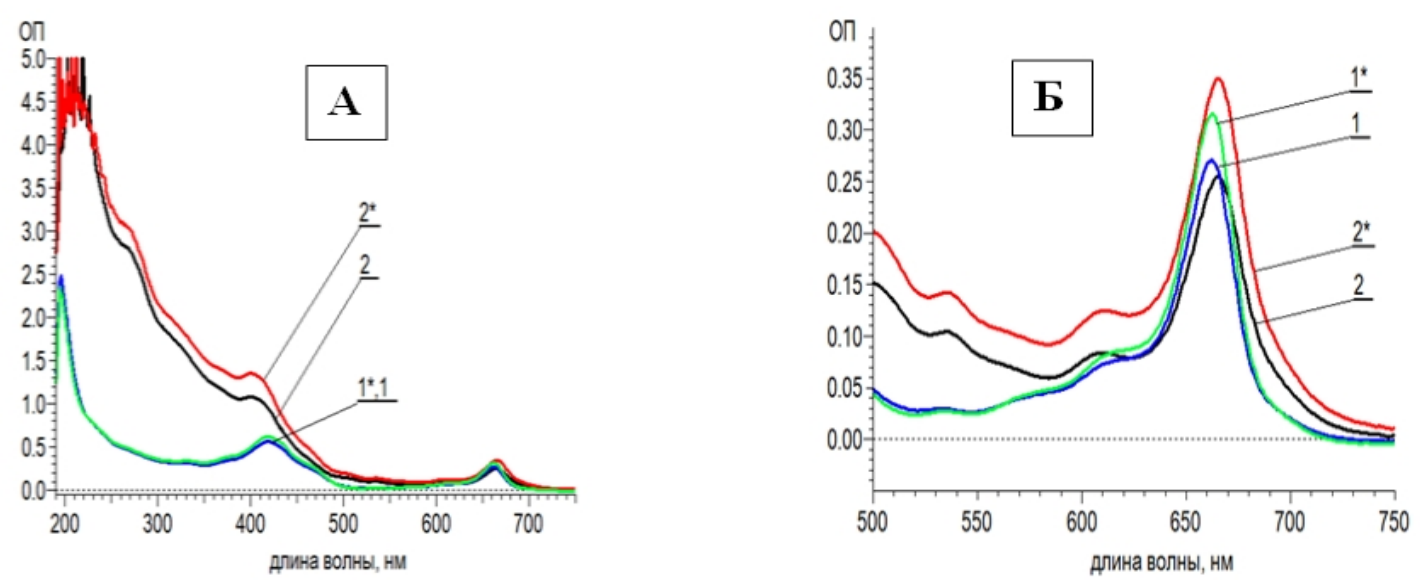

Рис. 8. А - спектры оптического поглощения исходных этанольных Jemo (D-I) - 1, водно-этанольных экстрактов Jето (D-II) - 2; после облучения (D= 18 кГр) этанольных экстрактов Јето (D-I) - 1* и водноэтанольных экстрактов Jето (D-II) - 2*; Б - спектры оптического поглощения (580-700 нм)

хлорофилловых фракций исходных этанольных экстрактов Jето (D-I) - 1 и водно-этанольных экстрактов Jето (D-II) - 2 и соответственно после облучения - 1* и - 2* 
Сравнение спектров исходных этанольных экстрактов микроводорослей Cylindrotheca closterium и экстрактов из облученных сухих образцов позволяет говорить о высокой радиационной стабильности биологически активных соединений при дозах облучения, используемых при стерилизации. Совершенно другие радиационно-химические процессы протекают с участием БАС водорослей, когда они находятся в растворах. Причем более активное разрушение зарегистрировано в ацетоновых растворах экстрактов, которые часто используются в промежуточных стадиях биотехнологии морекультуры.

Можно привести дополнительные данные по хранению водорослей в сухом виде в течение длительного времени. Результаты исследования сохранения фукоксантина в микроводорослях Cylinrotheca при

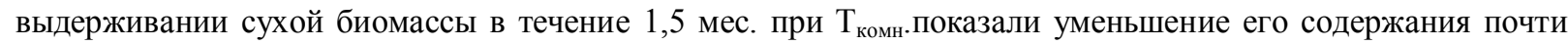
в 2 раза. При хранении в сухом виде макроводорослей Jemo и Jenit в течение 1,5 года содержание хлорофиллов уменьшилось только на 20\% .

\section{Bыводы}

1. Проведено сравнение спектров исходных этанольных и ацетоновых экстрактов микроводорослей Cylindrotheca closterium и макроводорослей Jeто и Jenit, выделенных из сухих образцов водорослей и из образцов этих же водорослей, предварительно облученных в сухом виде.

2. Полученные данные позволяют сделать вывод о высокой радиационной стабильности биологически активных соединений в водорослях, облученных в сухом виде при дозах, используемых при стерилизации (15-20 кГр).

3. Показано, что в этанольных и ацетоновых растворах соединения хлорофилловой группы обладают высокой чувствительностью по отношению к воздействию ионизирующего излучения (даже малых доз, $\sim 0,3-0,5$ кГр).

4. Сравнение радиационно-химических превращений и стабильности экстрактов водорослей Laminaria japonica (Республика Мьянма) позволило сделать вывод, что выход экстрагируемых веществ и радиационная чувствительность выше в образцах Jenit.

5. Зарегистрировано некоторое увеличение содержания хлорофиллов в этанольных и водноэтанольных экстрактах из облученных образцов водорослей Laminaria japonica Jemo u Jenit.

\section{Список литературы}

1. Takaichi S. Carotenoids in algae: Distributions, biosynthesis and functions // Mar. Drugs. 2011. N9. Pp. 1101-1108.

2. Kotake-Nara E., Kushiro M., Zhang H. et al.Carotenoids effect proliferation of human prostate cancer cells // J. Nutr. 2001. N131. Pp. 3303-3306.

3. Peng J., Yuan J.-P., Wu C.-F., Wang J.-H. Fucoxanthin, a Marine Carotenoid Present in Brown Seaweeds and Diatoms: Metabolism and Bioactivities Relevant to Human Health // Mar. Drugs. 2011. N9. Pp. 1806-1828.

4. Парамонова Л.И., Лизунков А.Ф., Милованов В.К. Взаимодействие каротиноидов с супероксид анионрадикалом в связи с их стабилизирующим действием при крио консервации // Доклады ВАСХНИЛ. 1989. T. 11. C. 30.

5. Прохорова Л.И., Ревина А.А. Роль лабильных комплексов с кислородом в антиоксидантной активности каротиноидов // Радиационная биология. Радиоэкология. 2000. Т. 40. №2. С. 156.

6. Пикаев А.К. Современная радиационная химия: Экспериментальная техника и методы. М., 1985. 375 с.

7. Тхан Тайк, Ревина А.А., Лозинина С.С., Магомедбеков Э.П. Биологически активные экстракты (спиртовые) из бурых водорослей laminaria japonica и их радиационная стабильность // Сборник научных трудов Всероссийской конференции «От растения к препарату: традиции и современность», посвященной 95-летию со дня рождения профессора А.И. Шретера, 23-24 апреля 2014 г. М., 2014. С. 277-281.

8. Ревина А.А., Тхан Тайк, Лозинина С.С, Магомедбеков Э.П. Биологически активные экстракты из бурых водорослей LAMINARIA JAPONICA и их радиационная стабильность // Материалы 2-й Международной научнопрактической конференции «Сопроводительная фитотерапия в онкологии». М., 2015. С. 145-146.

9. Лозинина С.С., Тхан Тайк, Железнова С.Н., Чекмарь Д.В., Геворгиз Р.Г., Нехорошев М.В., Ревина А.А. Оптические свойства биологически активных соединений из макро- и микроводорослей // Сборник тезисов IV международной конференции «Супрамолекулярные системы на поверхности раздела». Туапсе, 2015. С. 106.

10. Ревина А.А., Геворгиз Р.Г., Лозинина С.С., Железнова С.Н., Тхан Тайк, Павлов Ю.С., Нехорошев М.В., Рябушко В.И. Оптические свойства и радиационная стабильность экстрактов морской диатомеи Celindrotheca Closterium (Ehrenb) Reimann Et Lewin // Сорбционные и хроматографические процессы. 2016. Т. 16, №2. C. 173-182. 
Than Htaik*, Revina A.A., Lozinina S.S., Magomedbekov E.P. COMPARISON OF RADIATION STABILITY OF CHLOROPHYLL FRACTIONS IN THE ETHONOL AND ACETONE EXTRACTS OF THE ALGAE LAMINARIA JAPONICA (MYANMAR)

D.I. Mendeleev University of Chemical Technology of Russia, ul. Heroew Panfilovtsev, 20/1, Moscow, 125480 (Russia), e-mail: thanhtaik.iron@gmail.com

The optical properties and radiation stability of the alcoholic (ethanol) and acetone extracts from brown algae Laminaria Japonica Jemo (D) and Jenit (M) were studied using the method of UV- VIS spectrophotometry. The spectra of optical absorption of the original extracts and their changes at different dilution solvents was registered. It is shown that the nature of algae, the method of cultivation, nature of the solvent effect on the efficiency of extraction of valuable biologically active compounds, including the most important ones are carotenoids and chlorophylls. In this work the special attention was devoted to the study of radiation-chemical transformations of alcohol (ethanol), acetone, water-ethanol (50\%) and water-acetone (50\%) solutions of extracts of algae under various conditions of simulation of redox reactions due to saturation of the irradiated solutions of different gases: oxygen, argon, or nitrous oxide. The radiation-chemical stability of chlorophyll fractions in different species of algae depending on the conditions of radiolysis was determined. It is known that the chlorophylls are often used in pharmacology as a food colorant, and in the present time as components of photosensitive layers in the nanophotonics. The obtained results on radiation sensitivity of biological compounds from algae can be used to assess their stability under radiation sterilization of raw materials and medicines.

Keywords: algae, extracts, chlorophyll, spectrophotometry, ionizing radiation, $\gamma$-rays, accelerated electrons, the radiation stability, radiation sensitivity.

\section{References}

1. Takaichi S. Mar. Drugs., 2011, no. 9, pp. 1101-1108.

2. Kotake-Nara E., Kushiro M., Zhang H. et al. J. Nutr., 2001, no. 131, pp. 3303-3306.

3. Peng J., Yuan J.-P., Wu C.-F., Wang J.-H. Mar. Drugs, 2011, no. 9, pp. 1806-1828.

4. Paramonova L.I., Lizunkov A.F., Milovanov V.K. Doklady VASKhNIL, 1989, vol. 11, p. 30. (in Russ.).

5. Prokhorova L.I., Revina A.A. Radiatsionnaia biologiia. Radioekologiia, 2000, vol. 40, no. 2, p. 156. (in Russ.).

6. Pikaev A.K. Sovremennaia radiatsionnaia khimiia: Eksperimental'naia tekhnika i metody. [Modern Radiation Chemistry: Experimental equipment and methods]. Moscow, 1985, 375 p. (in Russ.).

7. Tkhan Taik, Revina A.A., Lozinina S.S., Magomedbekov E.P. Sbornik nauchnykh trudov Vseros-siiskoi konferentsii «Ot rasteniia k preparatu: traditsii $i$ sovremennost'», posviashchennoi 95-letiiu so dnia rozhdeniia professora A.I. Shretera. [Collection of scientific works of the All-Russian Conference "From the plant to the drug: Tradition and Modernity", dedicated to the 95th anniversary of birthday of Professor A.I. Schroeter]. 23-24 april 2014, Moscow, 2014, pp. 277-281. (in Russ.).

8. Revina A.A., Tkhan Taik, Lozinina S.S, Magomedbekov E.P. Materialy 2-i Mezhdunarodnoi nauchno-prakticheskoi konferentsii «Soprovoditel'naia fitoterapiia v onkologii». [Proceedings of the 2nd International Scientific and Practical Conference "Supporting herbal medicine in oncology."]. Moscow, 2015, pp. 145-146. (in Russ.).

9. Lozinina S.S., Tkhan Taik, Zheleznova S.N., Chekmar' D.V., Gevorgiz R.G., Nekhoroshev M.V., Revina A.A. Sbornik tezisov IV Mezhdunarodnoi konferentsii «Supramolekuliarnye sistemy na poverkhnosti razdela». [Abstracts of the International Conference IV «Supramolecular system interface"]. Tuapse, 2015, p. 106. (in Russ.).

10. Revina A.A., Gevorgiz R.G., Lozinina S.S., Zheleznova S.N., Tkhan Taik, Pavlov Iu.S., Nekhoroshev M.V., Riabushko V.I. Sorbtsionnye i khromatograficheskie protsessy, 2016, vol. 16, no. 2, pp. 173-182. (in Russ.).

Received March 2, 2016

Revised July 25, 2016

\footnotetext{
${ }^{*}$ Corresponding author.
} 